\title{
Orgasm-induced Seizures: A Case Report and Review of the Literature
}

\author{
Orgazm ile Uyarılan Nöbetler: Bir Olgu Sunumu ve Literatürün Gözden Geçirilmesi
}

\author{
๑ Hüseyin Nezih Özdemir, (1) Kamran Samedli, ๑ Figen Gökçay, ๑ Ahmet Gökçay \\ Ege University Faculty of Medicine, Department of Neurology, Izmir, Turkey
}

\begin{abstract}
Certain types of stimuli can trigger epileptic seizures in patients with epilepsy. This phenomenon is defined as reflex seizure. Stimuli may be in visual, auditory, tactile, or cognitive forms, and orgasm may trigger epileptic seizures. A 42-year-old man was admitted to our department with orgasm-induced generalized seizures that had started 6 months ago. He was examined using electroencephalography and cranial magnetic resonance imaging, and was treated with levetiracetam and clobazam. His seizures were controlled well. In this article, we aim to present our case and review the literature on the subject.
\end{abstract}

Keywords: Orgasm, reflex, seizure

$\ddot{O} z$

Epilepsi hastalarında, belirli tipte uyaranlar epileptik nöbetleri tetikleyebilir. Bu antite refleks nöbetler olarak tanımlanır. Bu uyarı görsel, duysal, dokunsal ve bilişsel biçimde olabilir. Orgazm epileptik nöbetleri tetikleyebilir. Kırk iki yaşında erkek hasta 6 ay önce başlayan orgazm ile uyarılan jeneralize nöbetlerle kliniğimize başvurdu. Elektroensefalografi ve kraniyal manyetik rezonans görüntüleme ile tetkik edildi. Levetirasetam ve klobazam ile tedavi edildi. Nöbetleri kontrol altına alındı. Bu yazıda olgumuzun sunulması ve konuya ilişkin literatürün derlenmesi amaçlandı.

Anahtar Kelimeler: Orgazm, refleks, nöbet

\section{Introduction}

Epileptic seizures can be triggered by certain types of stimuli. This phenomenon is defined as reflex seizure (1). Reflex seizures occur in about $4 \%$ to $7 \%$ of patients with epilepsy. The prevalence is up to $21 \%$ in patients with generalized epilepsy. Stimuli may be visual, auditory, tactile, auditory, or cognitive. The most common type of reflex seizure is precipitated by visual stimuli (2). Electroclinically, reflex seizures can have focal or generalized semiology (3). Although orgasm is not listed among "precipitating stimuli for reflex seizures" (1), it is thought to be a trigger for seizures (2). Orgasm can aggravate the already sensitized neurons located in the areas responsible for seizures (2). Patients with reflex seizures may also have unprovoked seizures (3). Orgasm-induced seizures are much less frequently noted than other types of reflex seizures (2). In the literature, there is a limited number of cases of orgasm-induced seizures. Herein, we report a case of orgasminduced seizures and review the literature on this topic.

\section{Case Report}

A 42-year-old married man presented to our department with recurrent seizures. He had his first seizure 2 years ago while sleeping at night. The seizure was described as generalized tonicclonic, and seizures occurred about once a month thereafter. $\mathrm{He}$ had seizures only while sleeping. He was treated with $3000 \mathrm{mg}$ of levetiracetam per day at a local hospital. The patient only had one seizure during the six months of using levetiracetam. One year after the first seizure, he had a generalized tonic-clonic seizure a few seconds after ejaculation. Afterward, according to his wife, he fell to the bed unconscious. He had been completely normal during the foreplay. He experienced postictal confusion for less than 5 minutes. He did not describe an aura. Most of his seizures were triggered by his orgasms. This led to the avoidance of sexual intercourse. No information was given about seizures with masturbation. As reported by the patient, music, light, and visual patterns did not trigger seizures. In his past medical history, he had

Address for Correspondence/Yazışma Adresi: Hüseyin Nezih Özdemir MD, Ege University Faculty of Medicine, Department of Neurology, Izmir, Turkey Phone: +90 5388599138 E-mail: huseyinnezihozdemir@gmail.com ORCID: orcid.org/0000-0002-0651-7276

Received/Geliş Tarihi: 01.07.2020 Accepted/Kabul Tarihi: 25.12.2020

${ }^{\circ}$ Copyright 2021 by Turkish Neurological Society

Turkish Journal of Neurology published by Galenos Publishing House. 
no other illnesses. The family history likewise had no significant features.

His neurologic examination was completely normal. His blood chemistry tests and complete blood count results were also unremarkable. Cranial magnetic resonance imaging (MRI) was normal. Interictal electroencephalography (EEG) and sleep EEG were normal. Hyperventilation was not a contributing factor.

With this clinical information, the patient was diagnosed as having generalized epilepsy with reflex seizures. Valproic acid at $2000 \mathrm{mg}$ per day and carbamazepine at $1200 \mathrm{mg}$ per day were combined with levetiracetam therapy. Neither was beneficial. He thus began clobazam at $5 \mathrm{mg}$ twice a day along with levetiracetam. With this levetiracetam and clobazam combination, he had neither unprovoked seizures nor orgasm-induced seizures.

\section{Discussion}

We searched for "orgasm-induced epilepsy", "orgasm-induced seizures", "sexual seizures", and "sexual epilepsy" in PubMed, Google Scholar, and the Cochrane Database. We found 14 cases from eight publications (six case reports and two case series) $(4,5,6,7,8,9,10,11)$. Our case is thus the $15^{\text {th }}$ such case in the literature. A case of orgasm-induced epilepsy was first reported in 1960 (4). We analyzed these 15 cases to describe their demographic and clinical features (Table 1).

The mean age at the onset of orgasm-induced seizures was 34.3 (range, 20-45) years. Twelve of $15(80 \%)$ patients were aged between 20 and 40 years. Ten of $15(66 \%)$ patients were female. The mean onset age of female patients was 31.5 years, and the mean age at onset of male patients was $40(4,5,6,7,8,9,10,11)$.

The most frequently noted orgasm-induced seizure type was focal seizure with or without impaired awareness; 8 patients $(53 \%)$ had focal seizures. Two patients had focal to generalized seizures (8). Five patients had generalized tonic-clonic seizures. The time between orgasm and epileptic seizures varied from seconds to 2 hours. Patients may have both reflex and unprovoked seizures $(4,5,6,7,8,9,10,11)$. Ozkara et al. (8) published the case of a female patient with pure orgasm-induced generalized reflex epilepsy.

It was reported that $53 \%$ of patients had an intracranial lesion $(4,5,6,7,8)$. Central nervous system (CNS) tumors, traumatic sequelae, and hippocampal sclerosis were noted $(5,6,7,8)$. All but one of these patients had lesions in the right brain hemisphere $(4,5,7,8)$. One patient had a right parasagittal lesion and one had a bilateral temporal lesion $(7,8)$. The most commonly affected right hemisphere lobe was the temporal lobe $(4,5,8)$. On the other hand, $47 \%$ of patients did not have a brain lesion or the lesion status was unknown $(6,8,9,10,11)$.

Ozkara et al. (8) published a case series with six patients. Three of these six patients' EEG recordings showed right temporal epileptiform activity. The other three patients' EEG recordings showed generalized or bilateral spikes and polyspikes or spikewave paroxysms. Apart from the patients which were published by Ozkara et al. (8), the interictal EEGs of four patients who had generalized seizures and were able to undergo EEG examination were normal $(9,10,11)$. Sengupta et al. (9) recorded ictal EEG results for a male patient during sexual intercourse and orgasm. The ictal EEG showed 2-2.5 Hz voltage rhythmic delta activity arising from the left temporal lobe and spreading to the right hemisphere.

Authors used phenytoin for treatment in early case reports (7). Five patients with orgasm-induced generalized seizures were treated with levetiracetam, valproic acid, and lamotrigine $(8,9,10,11)$. Three patients with orgasm-induced generalized seizures required combination therapy with antiseizure drugs $(9,10)$. Moreover, one patient used clobazam therapy when required, but eventually, an increase in seizure frequency was noted (9). In a case series with six patients, five patients had focal seizures. One patient was treated with carbamazepine. Four patients underwent surgery or were evaluated as surgery candidates (8).

Table 1. Demographic and clinical features of patients with orgasm-induced seizures

\begin{tabular}{|c|c|c|c|c|c|c|}
\hline Patient number & Authors, year & Age (years) & Sex & Seizure type & Lesion localization & Lesion type \\
\hline 1 & Hoenig and Hamilton, 1960 (4) & 23 & $\mathrm{~F}$ & FS & R Fr T & None \\
\hline 2 & Bancaud et al.,1971 (5) & 20 & $\mathrm{~F}$ & FS & $\mathrm{R} \mathrm{T}$ & Astrocytoma \\
\hline 3 & Remillard et al., 1983 (6) & 35 & $\mathrm{~F}$ & FS & Unknown & Unknown \\
\hline 4 & Remillard et al. 1983 (6) & 36 & $\mathrm{~F}$ & FS & Unknown & Traumatic scar \\
\hline 5 & Berthier et al., 1987 (7) & 43 & M & FS & $\mathrm{R}$ parasagittal & Traumatic scar \\
\hline 6 & Ozkara et al., 2006 (8) & 29 & $\mathrm{~F}$ & GTS & No lesion & None \\
\hline 7 & Ozkara et al., 2006 (8) & 32 & $\mathrm{~F}$ & FS to GTS & Bilateral T & None \\
\hline 8 & Ozkara et al., 2006 (8) & 27 & $\mathrm{~F}$ & FS to GTS & L Fr & $\mathrm{CD}$ \\
\hline 9 & Ozkara et al., 2006 (8) & 40 & $\mathrm{~F}$ & FS & $\mathrm{R} \mathrm{T}$ & HS \\
\hline 10 & Ozkara et al., 2006 (8) & 33 & $\mathrm{~F}$ & FS & $\mathrm{R} \mathrm{T}$ & HS \\
\hline 11 & Ozkara et al., 2006 (8) & 40 & $\mathrm{~F}$ & FS & No lesion & None \\
\hline 12 & Sengupta et al., 2010 (9) & 34 & M & GTS & No lesion & None \\
\hline 13 & Koç and Koç, 2011 (10) & 45 & M & GTS & No lesion & None \\
\hline 14 & Chaukimath and Patil 2015 (11) & 36 & M & GTS & No lesion & None \\
\hline 15 & Present case, 2021 & 42 & M & GTS & No lesion & None \\
\hline
\end{tabular}


We described the demographic and clinical features of orgasm-induced epilepsy patients above. In conclusion, most of the patients with orgasm-induced seizures were female and aged between 20 and 40 years $(4,5,6,7,8,9,10,11)$. The majority of the patients had focal motor seizures with or without impaired awareness $(4,5,6,7,8)$. EEG may show right temporal epileptiform activity and bilateral or generalized paroxysms (8). MRI showed CNS tumors, hippocampal sclerosis, and traumatic sequelae of the temporal lobes in some patients $(5,6,7,8)$. Wide- or narrowspectrum antiseizure drugs can be used depending on the seizure type $(4,5,6,7,8,9,10,11)$. Clobazam was used as an add-on therapy for two patients (9). The prognosis was not good for some patients; the seizures could not be controlled despite polytherapy with antiseizure drugs $(8,9)$. Physicians considered surgery as an option for selected patients (8).

Our patient had generalized epilepsy with reflex seizures. Patients with adult-onset seizures must be investigated for possible etiologic factors (12). The most common etiologic factor for adultonset seizures is stroke. Other possible factors are CNS infections, brain tumors, metabolic causes, and, rarely, acute disseminated encephalomyelitis (13). Blood chemistry tests, complete blood counts, EEG, and neuroimaging are highly recommended. Lumbar puncture should be performed in selected cases (12). Although it is not common, generalized genetic epilepsy (GGE) may arise in adulthood (14). Patients with mild GGE may present solely with generalized tonic-clonic seizures in later periods of their lives when exposed to certain kinds of stimuli (15). In a study with 313 patients with GGE, $13.4 \%$ of the patients had adult-onset generalized epilepsy. The onset age ranged between 18 and 55 years (14). On the other hand, it is also possible that patients with late-onset GGE may have had previously unrecognized epileptic events in their lives, such as myoclonus. Detailed anamnesis from such patients can make these events noticeable (15).

Our case differs from the majority of the cases in the literature. The two main differences are the patient was male and he had generalized seizures. Neuroimaging showed no structural abnormality and interictal EEG was normal. This response to clobazam treatment may contribute to the knowledge of the treatment of orgasm-induced epilepsy. We hope that our case and this brief narrative review will help in treating this rare type of epilepsy.

\section{Ethics}

Informed Consent: Informed consent was received. Peer-review: Externally and internally peer-reviewed.

\section{Authorship Contributions}

Concept: F.G., A.G., Design: F.G., A.G., Data Collection or Processing: H.N.Ö., K.S., Analysis or Interpretation: F.G., A.G., Literature Search: H.N.Ö., K.S., Writing: H.N.Ö.

Conflict of Interest: The authors have not declared any conflict of interest related to this article.

Financial Disclosure: No financial support was received from any institution or person for our study.

\section{References}

1. Engel J Jr. A proposed diagnostic scheme for people with epileptic seizures and with epilepsy: report of the ILAE task force on classification and terminology. Epilepsia 2001;42:796-803.

2. Okudan ZV, Özkara Ç. Reflex epilepsy: triggers and management strategies. Neuropsychiatr Dis Treat 2018;14:327-337.

3. Italiano D, Ferlazzo E, Gasparini S, et al. Generalized versus partial reflex seizures: a review. Seizure 2014;23:512-520.

4. Hoenig J, Hamilton CM. Epilepsy and sexual orgasm. Acta Psychiatr Neurol Scand 1960;35:448-456.

5. Bancaud J, Favel P, Bonis A, et al. Paroxysmal sexual manifestations and temporal epilepsy. Electroencephalogr Clin Neurophysiol 1971;30:371.

6. Remillard GM, Andermann F, Testa GF, et al. Sexual ictal manifestations predominate in women with temporal lobe epilepsy: a finding suggesting sexual dimorphism in the human brain. Neurology 1983;33:323-330.

7. Berthier M, Starkstein S, Leiguarda R. Seizures induced by orgasm. Ann Neurol 1987;22:394-395.

8. Ozkara Ç, Ozdemir S, Y1lmaz A, et al. Orgasm-induced Seizures: A Study of Six Patients. Epilepsia 2006;47:2193-2197.

9. Sengupta A, Mahmoudba A, Tun SZ, Goulding P. Orgasm-induced seizures: Male studied with ictal electroencephalography. Seizure 2010;19:306-309.

10. Koç RA, Koç A. Reflex epilepsy seizures triggered by sexual intercourse: two case reports. Turk Norol Derg 2011;17:51-54.

11. Chaukimath SP, Patil PS. Orgasm induced seizures: a rare phenomenon. Ann Med Health Sci Res 2015;5:483-484.

12. Elger CE, Schmidt D. Modern management of epilepsy: A practical approach. Epilepsy Behav 2008;12:501-539.

13. Kaur S, Garg R, Aggarwal S, Chawla SPS, Pal R. Adult onset seizures: Clinical, etiological, and radiological profile. J Family Med Prim Care 2018;7:191-197.

14. Cutting S, Lauchheimer A, Barr W, Devinsky O. Adult-onset idiopathic generalized epilepsy: clinical and behavioral features. Epilepsia 2001; $42: 1395-1398$.

15. Nicolson A, Chadwick DW, Smith DF. A comparison of adult onset and "classical" idiopathic generalised epilepsy. J Neurol Neurosurg Psychiatry 2004;75:72-74. 